\title{
Development of Local Historical Learning Resources South Sulawesi Based on Character Education in Department of Historical Education Faculty of Social Science at State University of Makassar
}

\author{
Bahri Baco*, Tuti Nuriah, Asmaniar Idris \\ Educational History Study Program, State University of Jakarta \\ *Corresponding author: bahrissejarah@gmail.com
}

\begin{abstract}
The purpose of this research is to develop a local history based on learning resource for character education. This study uses an Instructional Development Model (MPI) consisting of eight stages, namely needs analysis, instructional analysis, identification of learners characteristics, determining basic competencies, developing syllabus and SAP, designing assessment systems, developing learning modules, and formative evaluation implementation. The results of preliminary research indicate that the value of local character is not integrated in the learning process in History Education Program so that it needs to be made a learning resource which can be a reference in learning local history that students can identify, integrate and apply the character values in campus life as well as in social life. Sources of learning local history can increase the sense of care and interest in the regional domain of students. Local history can be an effective tool to stimulate a deeper interest and understanding of demand-oriented teaching. Events with the presence of prominent figures in historical events are expected to inspire students in the form of personal character because Holt's study of history in Frost not only enhances the understanding of the past, but also the understanding of future challenges [1].
\end{abstract}

\section{Keywords: learning resources, local history, character education, instructional development model (MPI)}

Cite This Article: Bahri Baco, Tuti Nuriah, and Asmaniar Idris, "Development of Local Historical Learning Resources South Sulawesi Based on Character Education in Department of Historical Education Faculty of Social Science at State University of Makassar.” American Journal of Educational Research, vol. 6, no. 3 (2018): 220-237. doi: 10.12691/education-6-3-10.

\section{Introduction}

Integrating the value of the character is important in learning because it provides benefits, among them can increase motivation and learning achievement, emotional intelligence, improve skills, solve life problems and can provide a meaningful experience [2] Peterson and Seligman (2004) in Boe, Bang and Nielsen argue that virtue and strength of character can be found in all cultures and considered universal [3], including cultural values possessed by the people of South Sulawesi (Bugis, Makassar and Toraja) have universal character values.

Character education in principle is value education that involves aspects of knowledge (cognitive), feelings, and actions. The limited character education of moral ignorance is inadequate, Linkona (2013) in the Pane explained that moral intelligence includes: conscience, self- perception, empathy, kindness, and humility. The development of the interrelated moral component is the requirement of the application of character education in developing moral intelligence [4].

Cheng (1989) in Vickers explained about local history.
First, local history enhance understanding of local settings, apply a sense of identity to the community, and enable search and interest in cultural heritage. Secondly, Local history increase the chance of using teaching methods with a source that aims to encourage analytical and investigative skills. Field studies showed that museum visits and activity approaches make history learning interesting [5].

The development of local history-based learning sources of character education in the form of modules facilitates the understanding and recall of the material presented. The language is easily understood to be an important effort done in presenting the material on the learning module. [6] Sources of learning on local history based on character education developed not entirely based on syllabus or lecture unit (SAP), but added other material. For example, character education as a source of character value of the people of South Sulawesi and the integration of character values. The value of characters to be developed in the local history learning source is; the value of the character of maradeka (democracy), the value of the getteng character (firmness), the value of lempu characters (honest), the value of warani character (dare), the value of the sitinaja character (decency). 
Observations and experiences of researchers in the learning of local history in Department Of Historical Educatian Social Science Faculty at State University of Makassar illustrates that the reference used in the learning of local history does not integrate the value of characters so that it becomes an obstacle for students in identifying the character values contained in the learning of local history. Local history references are available only to discuss specific events and figures. The character values are contained in messages (Paseng), (lontara) and the life principle of (siri na pace) which serve as the life principle of the characters (to acca) the past. Various historical events in South Sulawesi should be understood by students as strengthening local genius.

\section{Research Methods}

This research is a research and development (R \& D) with reference to model developed Atwi Suparman, namely MPI. Pre-development is done by observation and initial data collection. Data were collected through literature studies and field studies. The instrument details are formulated to be the observation and interview guidelines for use at the preliminary research stage. Preliminary research was conducted with qualitative descriptive approach with observation technique, interview and document review.

the reflective part contains the researcher's response to what is observed to be used as a benchmark in order to analyze the data collected. There are three stages in the preliminary study: (1) data collection; (2); data reduction, and (3) data analysis and conclusions. Needs analysis consists of an assessment of the communicative needs of students and techniques to achieve specific teaching objectives. The purpose of requirement analysis is to gather information about students and determine the objectives and situations of the learning environment [7].

The resulting learning modules and guidelines can assist lecturers and students in the learning process in understanding the various character values as a source of local history learning that can give significant effect to the lives of present and future generations. This learning resource product is packed with narrative text along with photographs of various historical sites that can support the factuality and truth of events occurring in South Sulawesi. This is done to provide information to learners, the general public and educators. According to Richards (1992) in Haque that needs analysis is the process of determining the needs of learners or groups of learners to determine needs according to priority. Meanwhile, according to Briendly (1984) in Haque needs analysis are desires, demands, expectations, motivations, shortcomings, constraints and requirements [8].

\section{Literature Review}

The learning model becomes the foundation to produce effective, efficient and enjoyable learning outcomes planning. Learning model that has been arranged systematically and consistent with the theory of learning on the basis of model, effective to help students learn in accordance with the specific objectives of the model. [9]

The learning model is a plan or a pattern used as a guideline in planning classroom learning or learning in tutorials and for determining learning tools including books, films, computers, curriculum, and others.

In an educational environment, an important factor in improving student understanding is the characteristics of the learning approach used, such as search for meaning, relevance, application, and relationships with other experiences [10].

Branch (2009) in Mutlu suggests instructional design is an iterative process of planning performance goals, choosing instructional strategies, choosing media and choosing or creatingmaterials and final evaluation [11]. Moore and Kearsley (1996) in Martin argue that Learning design is a well structured learning development system that uses objectives, related teaching strategies, systematic feedback, and evaluation. Learning design is also defined as science to create detailed specifications for the design, development, evaluation, and maintenance of instructional materials that facilitate learning and performance [12]. Spector defines instructional design as a methodology to enable educators / designers to make more informed decisions about how to design learning activities and interventions, which pedagogically inform and effectively utilize appropriate resources and technologies, including resource design and individual learning activities to design levels curriculum. The design of the empire as a research and development area includes the collection of empirical evidence to understand the process of designing and developing various resource learning designs, tools and activities [13].

Development of learning as learners and learning managers or as an independent developer differentiated two kinds of development according to Dick and Carey (2009) in Yaumi, namely: 1) the development of learning as well as teachers, lecturers, or instructors; 2) learning developers who are not teachers, lecturers, or instructors [14]. Suparman (2012) in Yaumi suggests from the aspect of the form of learning materials in terms of system implementation and development are classified in three forms; 1) self-learning system, 2) face-to-face learning system, 3) combined learning system [15]. One of the goals of developing learning resources in this research is to realize the students can learn independently. Candy (1991) in The Higher Education Academy argues that selflearning are: 1) an educational process, method and philosophy, gaining knowledge with its own business and developing the ability for critical investigation and evaluation; 2) includes freedom of choice in determining learning objectives within certain limits; 3) freedom of process to implement the objectives; 4) increasing the responsibility of education to students to achieve the goals and value of learning [16].

According to Merrill (2007, 2009) in Reigulth the learning method consists of 5 principles, namely; centering, activation, demonstration, application, and integration. Although these principles apply universally to all instructional situations, each principle is implemented to vary from one situation to another in order to provide high-quality instruction [17]. Caladine pointed out that the guidelines for selecting source mediums of learning are by analyzing statements, namely: (1) that learning resources 
are chosen in accordance with the learning objectives, (2) what learning resources are physically available to learners. (3) the safest learning resource used by the learner. (4) can improve learning motivation. (5) the use of certain learning resources because of the pressure or coercion of certain parties. (6) convenient for teachers. (7) students have sufficient knowledge and skills on how to use the learning resources. (8) thelecturer has sufficient knowledge and skills on how to use the learning resources (9) the type of media that can be used. (10) Types of media that students can use, (11) media that can support the main media [18]. Linkages to the use of various learning resources need to be tailored to the needs, efficiency, and effectiveness of their use. Selecting a variety of learning resources that educators should use should consider the following; Identify knowledge and skills gaps, effective assessment and measurement tools, interaction levels, instructional strategies, content complexity, content level changes, cognitive, affective, psychomotor levels and domains of learning objectives and costs [19].

One learning resource is considered suitable and relevant to self-learning is the module learning system. According to Kemp (1978) in Nurdin, the module is defined as an independent learning package containing one topic or unit of subject matter and the time required to study the module. While Houston \& Howson (1992) in Nurdin suggests that the learningmodule includes a set of activities aimed at facilitating students to achieve a set of learning objectives. Module learning system is considered more effective because module learning is one form of independent learning that can guide students to learn their own subject matter without any intervention of educator [20].

Historical learning sources include oral sources, written sources, and source objects. The oral source is the direct description of the actor or witness of the historical event of the person receiving the testimony verbally. Written sources are sources obtained from written relics that record events that occurred in the past, such as inscriptions, charters, documents, chronicles, manuscripts, newspapers, reports, recordings, and so on. The source of the object is the historical source derived from the relics of cultural objects, such as tools, weapons, statues, jewelry, buildings, and other cultural results. Historical learning sources consist of oral sources, written sources, and source objects. Historical learning sources can be tangible books, research reports, journals, literary works or messages, people, materials and the environment.

\section{Research Result}

\subsection{Eligibility of Learning Resources}

After the local history learning module based on character education is completed, the next step is validation or expert test. It is intended to obtain feedback on the feasibility of the developed product. Expert assessment is relevant to all aspects of the internal modeling process, including setting assumptions, governance, documentation and validation. Expert judgment is used to set assumptions and parameters, for completeness, accuracy, and so on [21].

Expert tests on this research and development product, consisting of design experts, media specialists and Local History experts.

\subsubsection{Eligibility of Learning Resources by a Learning Design Expert}

Design experts who assess the feasibility of this development product are Prof. Dr. Nurdin Ibrahim, M. Pd (UNJ) and Dr. Ir. Rusmono, M. Pd (UNJ). He is an expert in the field of learning technology both at the level of theory and practical. Experimental results of the design of learning is presented in the following table:

Table 1. The results of the module feasibility assessment by a learning design expert (Prof. Dr. Nurdin Ibrahim, M. Pd)

\begin{tabular}{|c|c|c|c|}
\hline No & Evaluation Aspect & Assessment Description & Score \\
\hline \multirow[t]{23}{*}{1} & \multirow[t]{23}{*}{ Material } & Clarity of general engagement goals & 5 \\
\hline & & Clarity of special lecture objectives & 5 \\
\hline & & ICT supports ITU achievement & 4 \\
\hline & & Material in accordance with TIU & 5 \\
\hline & & Material in accordance with ICT & 4 \\
\hline & & ICT formulation uses operational word & 5 \\
\hline & & ICT formulation does not contain multiple interpretations & 5 \\
\hline & & The material matches the theme or topic & 5 \\
\hline & & Method in accordance with the achievement of the desired competence & 5 \\
\hline & & Method according to student condition & 5 \\
\hline & & Lecture methods used vary & 3 \\
\hline & & Method according to the media used & 3 \\
\hline & & Method according to the characteristics of the material & 4 \\
\hline & & Lecture method chosen according to specified time allocation & 5 \\
\hline & & The material is relevant to the concept to be explained & 5 \\
\hline & & Interesting example for students & 5 \\
\hline & & Evaluation / test refers to the objectives / competencies that have been set & 5 \\
\hline & & Evaluation refers to previously learned concepts & 5 \\
\hline & & The evaluation takes into account the degree of difficulty & 5 \\
\hline & & Evaluation is easy to understand & 5 \\
\hline & & The existence of lecturing process by doing the exercises and tests & 5 \\
\hline & & Evaluation motivates students to learn things that have not been mastered/ new & 3 \\
\hline & & The accuracy of feedback after doing the evaluation & 4 \\
\hline
\end{tabular}




\begin{tabular}{|c|c|c|c|}
\hline No & Evaluation Aspect & Assessment Description & Score \\
\hline \multirow[t]{2}{*}{2} & \multirow[t]{2}{*}{ Module component } & 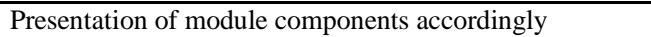 & 5 \\
\hline & & Systematical coherent presentation & 5 \\
\hline \multirow[t]{12}{*}{3} & \multirow[t]{12}{*}{ Language } & Ease of language understanding & 4 \\
\hline & & The accuracy of the use of EYD & 4 \\
\hline & & The accuracy of the use of the word is implied & 5 \\
\hline & & The language used matches the language of the student & 5 \\
\hline & & The demands of the logical thinking flow & 5 \\
\hline & & The use of communicative language style & 4 \\
\hline & & Language stimulates readers' activity & 4 \\
\hline & & Ease of understanding the meaning of sentences & 4 \\
\hline & & Conformity of sentence structure with SPOK & 5 \\
\hline & & Punctuation clarity used & 4 \\
\hline & & Relevance between sentences & 5 \\
\hline & & Consistency of terms within the module / product & 4 \\
\hline
\end{tabular}

Source: processed by researchers, 2017.

Based on the feasibility assessment by the design expert of learning (Prof. Dr. Nurdin Ibrahim, M. Pd), some inputs are obtained, 1) general course objectives are still very low for student sizes in college, 2) lecturing methods are less varied, 3) test questions / evaluation does not match the high level of the Bloom domain, 4) the word teaching needs to be uniformed into learning.

The results of the assessment of the design expert of learning (Prof. Dr. Nurdin Ibrahim, M. Pd) obtained a percentage of $86 \%$. This means that the learning design of local history learning resources of South Sulawesi based on character education is categorized very well. The products developed have met the eligibility standards. The results of the improvement of suggestions or comments given can be seen in the learning module component of local history of South Sulawesi based on character education.

Table 2. The results of the module feasibility assessment by the instructional design (Dr. Ir Rusmono, M. Pd).

\begin{tabular}{|c|c|c|c|}
\hline No & Evaluation Aspect & Assessment Description & Score \\
\hline \multirow{23}{*}{1} & \multirow{23}{*}{ Material } & Clarity of general engagement goals & 5 \\
\hline & & Clarity of special lecture objectives & 5 \\
\hline & & ICT supports ITU achievement & 4 \\
\hline & & Material in accordance with TIU & 5 \\
\hline & & Material in accordance with ICT & 4 \\
\hline & & ICT formulation uses operational word & 5 \\
\hline & & ICT formulation does not contain multiple interpretations & 5 \\
\hline & & The material matches the theme or topic & 5 \\
\hline & & Method in accordance with the achievement of the desired competence & 5 \\
\hline & & Method according to student condition & 5 \\
\hline & & Lecture methods used vary & 3 \\
\hline & & Method according to the media used & 3 \\
\hline & & Method according to the characteristics of the material & 5 \\
\hline & & Lecture method chosen according to specified time allocation & 5 \\
\hline & & The material is relevant to the concept to be explained & 5 \\
\hline & & Interesting example for students & 5 \\
\hline & & Evaluation / test refers to the objectives / competencies that have been set & 5 \\
\hline & & Evaluation refers topreviously learnedconcepts & 5 \\
\hline & & The evaluation takes into account the degree of difficulty & 5 \\
\hline & & Evaluation is easy to understand & 5 \\
\hline & & The existence of lecturing process by doing the exercises and tests & 3 \\
\hline & & Evaluation motivates participants to learn things that have not been mastered / new & 4 \\
\hline & & The accuracy of feedback after doing the evaluation & 4 \\
\hline \multirow{2}{*}{2} & \multirow{2}{*}{ Module component } & Presentation of module components accordingly & 5 \\
\hline & & Systematical coherent presentation & 5 \\
\hline \multirow{12}{*}{3} & \multirow{12}{*}{ Language } & Ease of language understanding & 5 \\
\hline & & The accuracy of the use of EYD & 5 \\
\hline & & The accuracy of the use of the word isimplied & 5 \\
\hline & & The language used matches the language of the student & 5 \\
\hline & & The demands of the logical thinking flow & 4 \\
\hline & & The use ofcommunicativelanguage style & 5 \\
\hline & & Language stimulatesreaders' activity & 5 \\
\hline & & Ease of understanding the meaning of sentences & 4 \\
\hline & & Conformity of sentence structure with SPOK & 5 \\
\hline & & Punctuation clarityused & 4 \\
\hline & & Relevance between sentences & 5 \\
\hline & & Consistency of terms within the module / product & 5 \\
\hline
\end{tabular}

Source: processed by researchers, 2017. 
Based on the feasibility assessment by the design expert of learning (Dr. Ir. Rusmono, M.Pd), obtained some input; 1) guidance on improvement work, 2) Lecture Unit (SAP) in the column of lecture method used is not applied well, but in general the framework of the contents of the module is good.

The result of the assessment of the second instructional design expert (Dr. Ir. Rusmono, M. Pd) obtained a percentage of $89 \%$. This means that the learning design of South Sulawesi's local history module based on character education is included in the criteria very well. The products developed have met the eligibility standards. The results of the improvement of the suggestions or comments given can be seen in the local history module of South Sulawesi based on character education.

\subsubsection{Eligibility of Learning Resources by a Learning Media Specialist}

Based on the assessment of the feasibility by the learning media expert (Dr. Robinson Situmorang, M. Pd), obtained some inputs: 1) the appearance and layout must still be completely improved which includes the layout,
2) the selection of letters and layout letters, 3), color. The media used in the local history-based learning product character education corresponds to the material on each module. Strauss and Frost (1999) in Ruis, Wahyudin and Waluyo identified nine key factors influencing media selection are: institutional support, suitability of learning content, student characteristics, attitudes and skill levels, learning objectives, learning relationships, learning location, time and difficulty media [22].

The results of the assessment of the first learning media expert (Dr. Robinson Situmorang, M. Pd) obtained a percentage of $76 \%$. This means that the learning media of South Sulawesi's local history module based on character education are included in both criteria. The products developed have met the eligibility standards. The results of the improvement of the suggestions or comments given can be seen in the local history module of South Sulawesi based on character education. The products developed have met the eligibility standards. The results of the improvement of the suggestions or comments given can be seen in the local history module of South Sulawesi based on character education.

Table 3. Module feasibility assessment results by media experts (Dr. Robinson Situmorang, M. Pd).

\begin{tabular}{|c|c|c|c|}
\hline No & Evaluation Aspect & Assessment Description & Score \\
\hline \multirow[t]{2}{*}{1} & \multirow[t]{2}{*}{ Module size } & Conformity of product content to standard & 4 \\
\hline & & Compatibility with product content & 3 \\
\hline \multirow[t]{7}{*}{2} & \multirow[t]{7}{*}{ Design of module cover } & The appearance of layout elements on the cover has unity & 4 \\
\hline & & The composition and size of layout elements (title, author) are proportional. & 5 \\
\hline & & The color of the elements of the layout of the harmonic and clarify the function. & 3 \\
\hline & & Selection of integrated illustration drawings in South Sulawesi character values & 4 \\
\hline & & Selection of illustrated images implied local history of South Sulawesi & 4 \\
\hline & & $\begin{array}{l}\text { The size of the title of the book is more dominant and proportional than the size of the product name and } \\
\text { author name }\end{array}$ & 3 \\
\hline & & Not using too much combination of fonts & 4 \\
\hline \multirow[t]{9}{*}{3} & \multirow{9}{*}{ Product content design } & Placement of layout elements is consistent & 3 \\
\hline & & The separation between paragraphs is clear & 5 \\
\hline & & The separation between chapters is clear & 3 \\
\hline & & Print and proportional margins & 4 \\
\hline & & Spacing between text and illustrations accordingly & 5 \\
\hline & & Placement of titles of lectures, subtitles, and page / folio numbers do not interfere with understanding. & 3 \\
\hline & & The placement of illustrations and captions does not interfere with the contents of the material & 4 \\
\hline & & Placement of decoration / illustration as background does not interfere with title, text, page numbers. & 3 \\
\hline & & Placement of titles, subheads, illustrations, and captions does not interfere with understanding. & 5 \\
\hline \multirow[t]{7}{*}{4} & \multirow[t]{7}{*}{ Module typography } & It Does not use many types of letters & 4 \\
\hline & & Use of normal font size & 3 \\
\hline & & The width of the normal text arrangement & 4 \\
\hline & & Line spacing is consistent & 3 \\
\hline & & Spaces between normal letters & 3 \\
\hline & & The hierarchy of titles is clear, consistent and proportional & 5 \\
\hline & & $\begin{array}{l}\text { The use of illustrations in titles, subheadings, summaries, summative tests, exercises, case examples, } \\
\text { glossaries are consistent }\end{array}$ & 4 \\
\hline \multirow[t]{7}{*}{5} & \multirow[t]{7}{*}{ Layout } & Placement of chapter headings, sub-chapters and sub-chapters is consistent & 5 \\
\hline & & Consistency in the writing of chapter titles, sub chapters and chapters & 4 \\
\hline & & Illustration of description corresponds to the picture & 3 \\
\hline & & Writing illustration drawing 1 space & 4 \\
\hline & & Image illustration placement does not disturb material content & 5 \\
\hline & & Conformity or balance between drawing layout and illustrative description & 4 \\
\hline & & The location of the exercise, final training module, glossary and a list of consistent libraries & 5 \\
\hline \multirow[t]{4}{*}{6} & \multirow[t]{4}{*}{ Illustration of content } & Picture illustration depicted the value of character and local history & 3 \\
\hline & & Illustrations correspond to the theme of each chapter & 3 \\
\hline & & The size of the illustrations is consistent & 3 \\
\hline & & Creative and dynamic & 3 \\
\hline
\end{tabular}

Source: processed by researchers, 2017 
Table 4. Module feasibility assessment results by media experts (Dr. Nur Hikmah, M. Pd).

\begin{tabular}{|c|c|c|c|}
\hline No & Evaluation Aspect & Assessment Description & Score \\
\hline \multirow[t]{2}{*}{1} & \multirow[t]{2}{*}{ Module size } & Conformity of product content to standard & 4 \\
\hline & & Compatibility with product content & 4 \\
\hline \multirow[t]{7}{*}{2} & \multirow{7}{*}{$\begin{array}{l}\text { Design of module } \\
\text { cover }\end{array}$} & The appearance of layout elements on the cover has unity & 4 \\
\hline & & The composition and size of layout elements (title, author) are proportional. & 4 \\
\hline & & The color of the elements of the layout of the harmonic and clarify the function. & 5 \\
\hline & & Selection of integrated illustration drawings in South Sulawesi character values & 4 \\
\hline & & Selection of illustrated images implied local history of South Sulawesi & 4 \\
\hline & & $\begin{array}{l}\text { The size of the title of the book is more dominant and proportional than the size of the product name and } \\
\text { author name }\end{array}$ & 5 \\
\hline & & Not using too much combination of fonts & 5 \\
\hline \multirow[t]{9}{*}{3} & \multirow{9}{*}{$\begin{array}{ll}\text { Product } & \text { content } \\
\text { design } & \end{array}$} & Placement of layout elements is consistent & 3 \\
\hline & & The separation between paragraphs is clear & 3 \\
\hline & & The separation between chapters is clear & 3 \\
\hline & & Print and proportional margins & 3 \\
\hline & & Spacing between text and illustrations accordingly & 4 \\
\hline & & 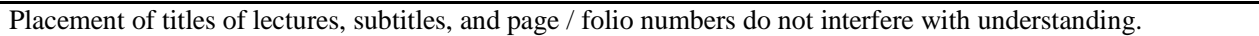 & 3 \\
\hline & & The placement of illustrations and captions does not interfere with the contents of the material & 4 \\
\hline & & Placement of decoration / illustration as background does not interfere with title, text, page numbers. & 5 \\
\hline & & Placement of titles, subheads, illustrations, andcaptions does not interfere with understanding. & 4 \\
\hline \multirow[t]{7}{*}{4} & \multirow[t]{7}{*}{ Module typography } & Not using too many fonts & 5 \\
\hline & & Use of normal font size & 4 \\
\hline & & Normal text sheet & 4 \\
\hline & & Line spacing is consistent & 3 \\
\hline & & Face-to-head spacing & 4 \\
\hline & & The hierarchy of titles is clear, consistent and proportional & 3 \\
\hline & & $\begin{array}{l}\text { The use of illustrations in titles, subheadings, summaries, summative tests, exercises, case examples, glossaries } \\
\text { are consistent }\end{array}$ & 4 \\
\hline \multirow[t]{7}{*}{5} & \multirow[t]{7}{*}{ Layout } & Placement of chapter headings, sub-chapters and sub-chapters is consistent & 3 \\
\hline & & Consistency in the writing of chapter titles, sub chapters and chapters & 3 \\
\hline & & Illustration of description corresponds to the picture & 5 \\
\hline & & Writing illustration drawing 1 space & 5 \\
\hline & & Image illustration placement does not disturb material content & 5 \\
\hline & & Conformity or balance between drawing layout and illustrative description & 4 \\
\hline & & The location of the exercise, final training module, glossary and a list of consistent libraries & 4 \\
\hline \multirow[t]{4}{*}{6} & \multirow[t]{4}{*}{ Illustration of content } & Picture illustration depicted character value and local history of South Sulawesi & 5 \\
\hline & & Picture illustrations according to each theme modules / learning activities & 4 \\
\hline & & The size of the illustrations is consistent & 4 \\
\hline & & Creative and dynamic & 3 \\
\hline
\end{tabular}

Source: processed by researchers, 2017.

Based on the feasibility assessment by the learning media expert (Dr. Nur Hikmah, M.Pd), some inputs were obtained, 1) the module cover must be equipped with several elements, such as publishing year, illustration drawing, module title. 2) the image on the cover is replaced which reflects the character of Makassar Bugis society, 3) the inconsistency of the image, mainly in terms of size.

The result of the assessment of the second learning media expert (Dr. Nur Hikmah, M. Pd) obtained a percentage of $79.44 \%$. This means that the learning media of South Sulawesi's local history module based on character education are included in both criteria. The products developed have met the eligibility standards. The results of the improvement of the suggestions or comments given can be seen in the local history module of South Sulawesi based on character education.

\subsubsection{Eligibility of Learning Resources by Expert of Materials}

Table 5. The result of the module feasibility assessment by the material expert (Prof. Dr. Hj Andi Ima Kesuma, M. Pd)

\begin{tabular}{|c|c|c|c|}
\hline No & Evaluation Aspect & Assessment Description & Score \\
\hline \multirow[t]{3}{*}{1} & \multirow[t]{3}{*}{ Eligibility of content } & Material completeness & 4 \\
\hline & & Material breadth & 4 \\
\hline & & Depth of matter & 4 \\
\hline \multirow[t]{6}{*}{2} & \multirow[t]{6}{*}{ Material accuracy } & Accuracy of concepts and definitions & 4 \\
\hline & & $\begin{array}{l}\text { Accuracy of historical facts combined with data about the value of characters in } \\
\text { every historical event }\end{array}$ & 3 \\
\hline & & $\begin{array}{l}\text { The accuracy of the examples illustrates the integration of character values in } \\
\text { local history lectures }\end{array}$ & $\begin{array}{l}3 \\
5\end{array}$ \\
\hline & & Accuracy of questions & 4 \\
\hline & & The accuracy of images and illustrations are integrated with the character values & 3 \\
\hline & & $\begin{array}{l}\text { Accuracy of bibliography which includes character education library and local } \\
\text { history of South Sulawesi }\end{array}$ & 4 \\
\hline
\end{tabular}




\begin{tabular}{|c|c|c|c|}
\hline No & Evaluation Aspect & Assessment Description & Score \\
\hline \multirow[t]{7}{*}{3} & \multirow[t]{7}{*}{ Presentation Supporters } & Summarize in each learning activity & 5 \\
\hline & & About exercises on every learning activity & 5 \\
\hline & & Instructions on practice & 5 \\
\hline & & About summative exercises of each module & 4 \\
\hline & & Key Answers about formative & 4 \\
\hline & & Glossary of each module & 5 \\
\hline & & References at the end of the module & 5 \\
\hline \multirow[t]{12}{*}{4} & \multirow[t]{12}{*}{ Language } & Accuracy of sentence structure & 5 \\
\hline & & The effectiveness of a sentence & 4 \\
\hline & & Rigidity of the term & 3 \\
\hline & & Use of the local term (Bugis-Makassar) & 5 \\
\hline & & Readability of character values & 4 \\
\hline & & The accuracy of the use of language rules & 4 \\
\hline & & Ability to motivate messages or information & 4 \\
\hline & & Ability to integrate character values in learning & 4 \\
\hline & & Suitability of intellectual development of students. & 5 \\
\hline & & Compliance with the level of emotional development of students. & 5 \\
\hline & & Consistency of term use & 4 \\
\hline & & Consistency of use of symbols or icons & 4 \\
\hline
\end{tabular}

Source: Data processed by researchers, 2017.

Based on the assessment of the feasibility by local history experts (Prof. Dr. Hj Andi Ima Kesuma, M.Pd), obtained some inputs, 1) the use of Bugis and Makassar terms that have been translated into the Indonesian language to be improved because the term Bugis Makassar in various sources - South Sulawei local history sources use the classic Bugis Makassar term that is difficult to translate by current students, 2) names mentioned in the local history events of South Sulawesi to be attached supporting data, eg photos, 3) Paseng or messages in the module material to be reproduced because it strongly supports the formation of local characters of students. 3) the questions presented are reproduced in Chapter 5 module because the module is the core of the learning materials you are developing.

The results of the assessment of local history material experts of South Sulawesi (Prof. Dr. Andi Ima Kesuma, M. Pd) obtained a percentage of $81.33 \%$. This means that the material of South Sulawesi's local history module based on character education is included in both criteria. The products developed have met the eligibility standards. The results of the improvement of the suggestions or comments given can be seen in the local history module of South Sulawesi based on character education.

Table 6. The result of the module feasibility assessment by the material expert (Prof. Dr. Darman Manda, M. Hum)

\begin{tabular}{|c|c|c|c|}
\hline No & Evaluation Aspect & Assessment Description & Score \\
\hline \multirow[t]{3}{*}{1} & \multirow{3}{*}{$\begin{array}{l}\text { Eligibility of } \\
\text { content }\end{array}$} & Material completeness & 4 \\
\hline & & Material breadth & 4 \\
\hline & & Depth of matter & 4 \\
\hline \multirow[t]{6}{*}{2} & \multirow[t]{6}{*}{ Material accuracy } & Accuracy of concepts and definitions & 4 \\
\hline & & Accuracy of historical facts combined with data about the value of characters in every historical event & 4 \\
\hline & & The accuracy of the examples illustrates the integration of character values in local history lectures & 5 \\
\hline & & Accuracy of questions & 4 \\
\hline & & The accuracy of images and illustrations are integrated with the character values & 3 \\
\hline & & The accuracy of the bibliography includes reference of character education and local history of South Sulawesi & 4 \\
\hline \multirow[t]{7}{*}{3} & \multirow{7}{*}{$\begin{array}{l}\text { Presentation } \\
\text { Supporters }\end{array}$} & Summarize in each learning activity & 5 \\
\hline & & About exercises on every learning activity & 5 \\
\hline & & Instructions on practice & 5 \\
\hline & & About summative exercises of each module & 5 \\
\hline & & Key Answers about practice & 5 \\
\hline & & Glosarium akhir modul & 4 \\
\hline & & Bibliography & 4 \\
\hline \multirow[t]{12}{*}{4} & \multirow[t]{12}{*}{ Language } & Ketepatan struktur kalimat & 3 \\
\hline & & Keefektifan kalimat & 4 \\
\hline & & Kebakuan istilah & 5 \\
\hline & & $\begin{array}{l}\text { Penggunaan istilah lokal (bahasa Bugis-Makassar) } \\
\end{array}$ & 5 \\
\hline & & Keterbacaan nilai karakter & 5 \\
\hline & & $\begin{array}{l}\text { Ketepatan penggunaan kaidah bahasa } \\
\end{array}$ & 5 \\
\hline & & Kemampuan memotivasi pesan atau informasi & 4 \\
\hline & & Kemampuan mengintegrasikan nilai karakter dalam pembelajaran & 3 \\
\hline & & Kesesuaian perkembangan intelektual mahasiswa. & 4 \\
\hline & & Kesesuaian dengan tingkat perkembangan emosional mahasiswa. & 5 \\
\hline & & Konsistensi penggunaan istilah & 5 \\
\hline & & Konsistensi penggunaan simbol atau ikon & 5 \\
\hline
\end{tabular}

Source: processed by the researcher, 2017. 
Based on the assessment of the feasibility by the local history material expert (Prof. Dr. Darman Manda, M. Hum), obtained some input, the use of the term Bugis and Makassar which has been dtranslate into the Indonesian language to be improved because the term Bugis Makassar in various sources of local history Sulawei South uses the classic Bugis Makassar language hard to translate by current students. The discussion of events is described chronologically. The figures mentioned in the local history events of South Sulawesi to attach supporting data, such as photographs. Paseng or message in the module material to be reproduced because it strongly supports the formation of local characters of students. The character values in each historical event to be reproduced.

The results of expert assessment of local historical materials South Sulawesi (Prof. Darman Manda, M. Hum) obtained a percentage of $84.14 \%$. This means that the learning materials of local history module South Sulawesibased character education, including the criteria very well. The products developed have met the eligibility standards. The improved results over a given suggestions or comments can be seen on the local history of South Sulawesi module based character education.

\subsubsection{Feasibility of Learning Resources by Users}

It needs to involve a local history learner based on character education with the consideration that educators are users of learning resources in learning. As a practitioner in development research are Dr. Abdul Rahman, M. Si and Amirullah, S. Pd, M. Pd. The results of the assessment are presented in the following table:

Table 7. The results of the feasibility assessment 1 (Dr. Abdul Rahman, M. Si)

\begin{tabular}{|c|c|c|c|}
\hline No & Reviewing aspects & Description Ratings & Score \\
\hline \multirow{3}{*}{1} & \multirow{3}{*}{ Quality module design } & Relations between inter-related learning materials. & 5 \\
\hline & & The learning objectives are presented before the material described. & 5 \\
\hline & & Fill or elaboration of learning materials is done in detail by integrating the value of the character. & 5 \\
\hline & & Coverage of the material described is always associated with the education of character. & 5 \\
\hline & & Each chapter is presented along with examples of questions or cases related to the value of character & 5 \\
\hline & & Presentation of a matter or case is helping students to understand the values of character. & 4 \\
\hline & & $\begin{array}{l}\text { References are presented in each material, enables students to discover more about the local historical } \\
\text { themes South Sulawesi, which can be integrated with the character value. }\end{array}$ & 5 \\
\hline & & The strategy to deliver lectures established in accordance with the characteristics of a diverse student. & 4 \\
\hline & & Learning strategies used in each material is highly relevant to character education. & 3 \\
\hline & & $\begin{array}{l}\text { The material is planned to stimulate the students to find out the integration of the values of characters } \\
\text { in learning. }\end{array}$ & 4 \\
\hline & & Local historical materials are described in chronological order. & 4 \\
\hline & & The dominance of educators in learning can be reduced. & 4 \\
\hline \multirow{2}{*}{2} & \multirow{2}{*}{$\begin{array}{l}\text { Compliance with the level of } \\
\text { student development }\end{array}$} & Compliance with the level of cognitive development of students. & 4 \\
\hline & & Compliance with the emotional level of social development of students. & 3 \\
\hline \multirow{2}{*}{3} & \multirow{2}{*}{ Keruntutan and unity ideas } & Keruntutan meaning of section / chapter / sub-chapter, paragraph / sentence. & 4 \\
\hline & & The link between the meaning of section / chapter / sub-chapter, paragraph / sentence. & 4 \\
\hline \multirow{5}{*}{4} & \multirow{5}{*}{$\begin{array}{l}\text { Engineering presentation of } \\
\text { lectures }\end{array}$} & $\begin{array}{l}\text { Learning materials from the general to the particular material, ranging from the general character } \\
\text { education to the integration of the character values in the local history of South Sulawesi. }\end{array}$ & 4 \\
\hline & & Centering on student & 4 \\
\hline & & Develop creativity and critical thinking of students. & 4 \\
\hline & & The material presented can mengembangangkan character of students. & 4 \\
\hline & & Developing the character value on each material. & 4 \\
\hline \multirow{5}{*}{5} & \multirow{5}{*}{ Supporting presentation } & Preliminary activities of learning & 5 \\
\hline & & Material Description. & 5 \\
\hline & & Summary. & 5 \\
\hline & & Exercise. & 5 \\
\hline & & Final training module & 5 \\
\hline \multirow{9}{*}{6} & \multirow{9}{*}{ design Content } & Placement and writing the title, subtitle / sub-chapters, captions, page numbers clearly. & 5 \\
\hline & & Printing field and proportional margins. & 5 \\
\hline & & Spacing between text accordingly. & 4 \\
\hline & & Structuring text and image design to attract the attention of students. & 4 \\
\hline & & Clarity of presentation of images with inter-related material. & 4 \\
\hline & & Illustration of the displayed image associated with character-based education. & 4 \\
\hline & & Do not use a lot of typeface. & 5 \\
\hline & & $\begin{array}{l}\text { Being able to express the meaning / significance of an object, particularly with respect to the value of } \\
\text { the character. }\end{array}$ & 4 \\
\hline & & The general layout of a dynamic and creative. & 4 \\
\hline
\end{tabular}

Source: processed by the researcher, 2017. 
Based on a feasibility assessment by user (Dr. Abdul Rahman, M.Si), acquired a few inputs, 1) typing laid out well because there are several pages of words one with another word distance is not uniform, 2) the displayed image should reflect history or the value character South Sulawesi, 3) the message in the language of the Bugis and Makassar should be spelled out in contemporary conditions.

The results of the assessment of local history local South Sulawesi-based character education (Dr. Abdul Rahman, M. Si.) Obtained a percentage of $84.57 \%$. This means that the module of the local history of South Sulawesi-based character education, including the criteria very well. The products developed have met the eligibility standards. The improved results over a given suggestions or comments can be seen on the local history of South Sulawesi module based character education.
Based on the assessment of eligibility by local history users (Amirullah, M.Pd), some inputs were obtained, 2) identification of local history materials based on local character education to be reproduced, 2) more varied lecture strategies, character education education, 3) drawings or reproduced illustrations, especially those related to the value of the characters developed, the question of the description added.

The results of the South African local history based on character education (Amirullah, S.Pd, M. Pd) obtained percentage of $90.86 \%$. This means that South Africa's local history module based on character education, is included in the criteria very well. The products developed have met the eligibility standards. The results of the improvement of the suggestions or comments given can be seen in the local history module of South Sulawesi based on character education.

Table 8. The results of the feasibility assessment of use of (Amirullah, S. Pd, M. Pd.)

\begin{tabular}{|c|c|c|c|}
\hline No & Reviewing aspects & Description Ratings & Score \\
\hline \multirow{3}{*}{1} & \multirow{3}{*}{ Quality module design } & Relations between inter-related learning materials & 5 \\
\hline & & The learning objectives are presented before the material described & 4 \\
\hline & & Fill or elaboration of learning materials is done in detail by integrating the value of character & 4 \\
\hline & & Cakupan materi yang diuraikan selalu dihubungkan dengan pendidikan karakter & 5 \\
\hline & & Setiap bab yang disajikan disertai dengan contoh soal atau kasus yang terkait dengan nilai karakter & 5 \\
\hline & & Penyajian soal atau kasus sangat membantu mahasiswa untuk memahami nilai karakter & 5 \\
\hline & & $\begin{array}{l}\text { Daftar rujukan dipaparkan pada setiap materi mempermudah mahasiswa untuk menelusuri lebih lanjut } \\
\text { tentang tema-tema sejarah lokal Sulawesi Selatan yang dapat diintegrasikan dengan nilai karakter }\end{array}$ & 4 \\
\hline & & $\begin{array}{l}\text { Strategi penyampaian pembelajaran yang ditetapkan sesuai dengan karakteristik mahasiswa yang } \\
\text { beragam }\end{array}$ & 4 \\
\hline & & Strategi perkuliahan yang digunakan pada setiap materi sangat relevan dengan pendidikan karakter & 4 \\
\hline & & $\begin{array}{l}\text { Materi yang direncanakan dapat merangsang mahasiswa untuk mengetahui integrasi nilai Karakter } \\
\text { dalam perkuliahan }\end{array}$ & 4 \\
\hline & & Materi sejarah lokal diuraikan secara kronologis & 5 \\
\hline & & Dominasi pendidik dalam perkuliahan dapat dikurangi & 4 \\
\hline \multirow[t]{2}{*}{2} & \multirow{2}{*}{$\begin{array}{l}\text { Kesesuaian dengan tingkat } \\
\text { perkembangan mahasiswa }\end{array}$} & Kesesuaian dengan tingkat perkembangan kognitif mahasiswa & 5 \\
\hline & & Kesesuaian dengan tingkat perkembangan sosial emosional mahasiswa & 4 \\
\hline \multirow{2}{*}{3} & \multirow{2}{*}{$\begin{array}{l}\text { Keruntutan dan kesatuan } \\
\text { gagasan }\end{array}$} & Keruntutan makna dalam bagian/bab/sub bab, paragraph/kalimat & 4 \\
\hline & & Keterkaitan makna dalam antar bagian/bab/sub bab, paragraph/kalimat & 5 \\
\hline \multirow[t]{5}{*}{4} & \multirow{5}{*}{$\begin{array}{l}\text { Tekhnik penyajian } \\
\text { perkuliahan }\end{array}$} & $\begin{array}{l}\text { Materi pembelajaran dari yang umum ke materi khusus, mulai dari pendidikan karakter secara umum } \\
\text { hingga integrasi nilai karakter dalam sejarah lokal Sulawesi Selatan }\end{array}$ & 4 \\
\hline & & Keterpusatan pada mahasiswa & 4 \\
\hline & & Mengembangkan kreatifitas, dan cara berpikir kritis mahasiswa & 5 \\
\hline & & Materi yang disajikan dapat mengembangangkan karakter mahasiswa & 5 \\
\hline & & Mengembangkan nilai karakter pada setiap materi & 5 \\
\hline \multirow{5}{*}{5} & \multirow{5}{*}{ Pendukung penyajian } & Pendahuluan Kegiatan belajar & 5 \\
\hline & & Uraian Materi & 5 \\
\hline & & Rangkuman & 5 \\
\hline & & Latihan & 4 \\
\hline & & Latihan akhir modul & 5 \\
\hline \multirow{9}{*}{6} & \multirow{9}{*}{ Desain isi } & Penempatan dan penulisan judul, subjudul/sub bab, keterangan gambar, angka halaman jelas & 4 \\
\hline & & Bidang cetak dan marjin proporsional & 4 \\
\hline & & Spasi antar teks sesuai & 4 \\
\hline & & Penataan desain gambar dan teks dapat menarik perhatian mahasiswa & 5 \\
\hline & & Kejelasan penyajian gambar dengan materi saling berkaitan & 5 \\
\hline & & Ilustrasi gambar yang ditampilkan terkait dengan pendidikan berbasis karakter & 5 \\
\hline & & Tidak menggunakan banyak jenis huruf & 4 \\
\hline & & Mampu mengungkapkan makna/arti dari suatu obyek, khususnya terkait dengan nilai karakter & 5 \\
\hline & & Layout secara umum dinamis dan kreatif & 5 \\
\hline
\end{tabular}

Source: processed by the researcher, 2017. 


\subsection{Effectiveness of Learning Resources}

The next step after the development of South-East Sulawesi-based learning resource-based education is validated and validated by experts and users. The testing process is carried out to ensure the effectiveness of the developed learning resources. Indication of its effectiveness can be seen from its usability aspect and its usefulness. Trials are conducted in three stages.

First, individualized trials with students (one to one learner). One to one pilot activity against revised product feasibility in the early stages intended to identify and mitigate the errors contained in the module from both material and design and media aspects. One to one involves 3 students.

Second, small group trials (small group). Altivitas small group trial by means of determining the 12 student class of 2014. The purpose of this test is to identify a shortage of learning resources Local History South Sulawesi-based character education has been revised, both in terms of content, design and media used and to know how the attitudes local history students to modules South Sulawesi-based character education. Third, a large group trial (field trial).

Recent trial involving a larger number of students ie 35 people. The test is done with the hope seen the effectiveness of the learning process of the local history teaching materials based character education with study results both in terms of content, design and media used and find out how the attitude of students to local history module South Sulawesi-based character education. The whole process of testing conducted at UNM. Another aspect to consider in student engagement is the ability of students academically. The grouping is divided into three, namely the student with the ability of low, medium and high-class and the same force.

Following exposure of the test results on the product development of learning resources of the local history of South Sulawesi-based character education undertaken.

\subsubsection{Individual testing (one to one learnet)}

Individual testing (one to one learnet) students of class 2014 named Rahmat Hussain Muhammad Ikbal and Marwah selected by lecture of local history. Interviews were conducted on February 13, 2016 held in lecturer room at Historical education in 60 minutes. Students are given examples of draft module-based learning resources of the local history of character education that refers to the instrument response to one to one. The results obtained describe the view as follows:

Table 9. Individual testing 1

\begin{tabular}{|c|c|c|c|}
\hline No & $\begin{array}{l}\text { Reviewing } \\
\text { aspects }\end{array}$ & Description Ratings & Score \\
\hline \multirow[t]{6}{*}{1} & \multirow[t]{6}{*}{ Content / material } & General physical appearance module & 5 \\
\hline & & The language used in the study material according to the condition of the student & 4 \\
\hline & & The language used in the presentation of the material of interest to students & 4 \\
\hline & & The language used is easy to understand & 5 \\
\hline & & The term used is easy to understand & 5 \\
\hline & & Summary described at the end of sections according to the material & 4 \\
\hline \multirow[t]{8}{*}{2} & \multirow[t]{8}{*}{ Design / media } & ICT and learning are clearly described TIU & 5 \\
\hline & & Lecture method used in accordance with the material & 4 \\
\hline & & The linkage between the material on each module & 5 \\
\hline & & $\begin{array}{l}\text { Presentation of images in accordance with the material related to local history and the character values in South } \\
\text { Sulawesi }\end{array}$ & 4 \\
\hline & & Display images on the material describes the value of character & 5 \\
\hline & & The material presented contains the character values & 5 \\
\hline & & Values displayed character according to the character values in South Sulawesi & 5 \\
\hline & & References are relevant to character education and local history of South Sulawesi & 5 \\
\hline
\end{tabular}

Source: processed by the researcher, 2017.

In general the response from trial one to one student in the name of Rachmat is from the aspect of the content / materials are as follows; the general appearance of the product cover the module is illustrated the value of community character with a photograph of Bugis Makassar Sultan Hasanuddin as a character representation bravery (warani), but the cover should be included reviews of the module content. The language used, particularly the use of the term Bugis Makassar help students to understand the various of messages (paseng) of scholars as well as from the various agreements between the kingdom. Translations into Indonesian various terms Bugis Makassar also very supportive in understanding the value of a character contained in the local history of South Sulawesi.
The method used in every SAP lectures are highly relevant to character of education. The linkage between the material interlinked with one another, nor examples provided are highly relevant to the material presented. The pictures illustration provided is related to the material, but their quantity is very less, so it needs to be added so that students can more easily understand any of the material presented. List of references used very well as a collaboration between the national history, local history of South Sulawesi in the form of books, journals that reveal the character values in the integration of the local history of South Sulawesi.

The results of individual testing on the first student of local history module South Sulawesi-based character education (Rahmat) obtained a percentage of $92.86 \%$. 
This means that the module of the local history of South Sulawesi-based character education, including the criteria very well. The products developed have met the eligibility standards. The improved results over a given suggestions or comments can be seen on local history module based character education.

Table 10. Individual testing 2

\begin{tabular}{|c|c|c|c|}
\hline No & Reviewing aspects & Description Ratings & Score \\
\hline \multirow{6}{*}{1} & \multirow{6}{*}{ Content / material } & General physical appearance module & 5 \\
\hline & & The language used in the presentation of the material in accordance with the conditions of student & 4 \\
\hline & & The language used in the presentation of the material of interest to students & 4 \\
\hline & & The language used is easy to understand & 5 \\
\hline & & The term used is easy to understand & 5 \\
\hline & & Summary described at the end of sections according to the material & 5 \\
\hline \multirow{8}{*}{2} & \multirow{8}{*}{ Design / media } & ICT and learning are clearly described TIU & 5 \\
\hline & & Lecture method used in accordance with the material & 5 \\
\hline & & The linkage between the material on each module & 5 \\
\hline & & $\begin{array}{l}\text { Presentation of images in accordance with the material related to local history and the character values in South } \\
\text { Sulawesi }\end{array}$ & 3 \\
\hline & & Display images on the material describes the value of character & 5 \\
\hline & & The material presented contains the character values & 5 \\
\hline & & Values displayed character according to the character values in South Sulawesi & 5 \\
\hline & & References are relevant to character education and local history of South Sulawesi & 5 \\
\hline
\end{tabular}

Source: processed by the researcher, 2017.

Based on data obtained from testing a small group in the name of Mohammed Ikbal that the general view the cover of the product of this research is to describe the value of the public character of South Sulawesi. In addition to showing character Sultan Hasanuddin (towarani), also featuring a symbol of the courage of the Bugis Makassar, namely phinisi (boat). In terms of the language used is very good because it comes with Indonesian translate greatly assist students in understanding the local character values Bugis Makassar. The material presented and the image displayed in the module describes the value of Bugis Makassar character so it is relevant to the material in the module.

The results of individual testing on a second student in local history module local South Sulawesi-based character education (Muhammad Ikbal) obtained a percentage of $94.29 \%$. This means that the module of the local history of South Sulawesi-based character education, including the criteria very well. The products developed have met the eligibility standards. The improved results over a given suggestions or comments can be seen on local history module based pendid South Sulawesi fish character.

Table 11. Individual testing 3

\begin{tabular}{|c|c|c|c|}
\hline No & Reviewing aspects & Description Ratings & Score \\
\hline \multirow{6}{*}{1} & \multirow{6}{*}{ Content / material } & General physical appearance module & 5 \\
\hline & & The language used in the presentation of the material in accordance with the conditions of student & 4 \\
\hline & & The language used in the presentation of the material of interest to students & 5 \\
\hline & & The language used is easy to understand & 5 \\
\hline & & The term used is easy to understand & 5 \\
\hline & & Summary described at the end of sections according to the material & 4 \\
\hline \multirow{8}{*}{2} & \multirow{8}{*}{ Design / media } & ICT and learning are clearly described TIU & 4 \\
\hline & & The learning method used in accordance with the material & 4 \\
\hline & & The linkage between the material on each module & 4 \\
\hline & & $\begin{array}{l}\text { Presentation of images in accordance with the material related to local history and the character values in } \\
\text { South Sulawesi }\end{array}$ & 4 \\
\hline & & Display images on the material describes the value of character & 4 \\
\hline & & The material presented contains the character values & 5 \\
\hline & & Values displayed character according to the character values in South Sulawesi & 4 \\
\hline & & References are relevant to character education and local history of South Sulawesi & 5 \\
\hline
\end{tabular}

Source: processed by the researcher, 2017. 
In general the response from Husain Marwah about local history module South Sulawesi is included in both categories. In terms of the language used in accordance with the character of the students. Classic Makassar Bugis language is poorly understood by the students are presented with the present Makassar Bugis language so it helps the students to understand the character values in the event of local history and languages of South Sulawesi lontara and paseng. Pictures and illustrations also relevanced with current events, for example the problem of honesty picture presented is a photo Andi Mallarangeng. The material presented characters that include characters Maradeka, Lempu, getting, sitinaja and warani is the character value that used as reference in campus life, both in organization and academic activities.

The results of individual testing of students both on local history module local South Sulawesi-based character education (Niswa Husain) obtained a percentage of $75.71 \%$. This means that the module of the local history of South Sulawesi-based character education, including in both criteria. The products developed have met the eligibility standards. The improved results over a given suggestions or comments can be seen on the local history of South Sulawesi module based character education.

\subsubsection{The small group trial (small group)}

The small group trial (small group) involving 12 students. With reference to the model of instrument testing small group format with a questionnaire made in the form of a statement which amounts to 15 items with a choice of options between strongly agree (ss) $=5$, agree $(\mathrm{s})=4$, normal (n) $=3$, disagree (TS) $=2$ and strongly disagree $(\mathrm{STS})=1$.

The results of questionnaire analysis reflect the views of the students with the following statements: 1) description of the lecture material using a phrase that is easy to understand its meaning. 6 out of 12 respondents (50\%) answered strongly disagree, 5 (41.66\%) answered agree, 1 person (8.33\%) normal answer. Based on the case concluded use of the phrase in the module easy to understand. This is illustrated in one of the student's comments that the use of the phrase in local history-based learning modules for character education in accordance with the character of students, besides translate languages into Indonesian Bugis Makassar is helping students to find out the character values in historical events.

The material of local history is presented chronologically. Answering strongly agree 3 people (25\%), 6 people (50\%) agree, 2 (16.66) answered normally and 1 (8.33) answered disagree. Based on the data, it is concluded that the presentation of local history of South Sulawesi based on character education has fulfilled the aspect of historical presentation that is chronologically. This is illustrated in one of the comments that the material presented in the module corresponds to the historical aspect of the chronological order.

The material presented character education in general. 7 (58.33\%) answered strongly agree, 2 (16.66\%) answered agree, 3 (25\%) normal answer. Based on the results of the interview are illustrated that the general character of educational material to render properly on character education material aspects are integrated in the learning of local history. This is illustrated in one of the comments that the source of local history in the form of a module, in addition to describing the character values in general also discussed the character values that are integrated in the teaching of history.

Material uncover the source of the community character of South Sulawesi. Answered strongly agree is 1 (8.33), agreed to 5 people (41.66\%), and 2 (16.66\%) answered normal and 3 (25\%) answered disagree. Based on the data concluded that the module of the local history of South Sulawesi-based character education has been good from the disclosure of the source code of South Sulawesi, although there were respondents of 3 (25\%) who do not agree with that because some other source that can be used as a source of character society, for example elong which is explicitly not covered by the modules.

The material of local history are integrated in the value of South Sulawesi community character. 4 (33.33\%) answered strongly agree, 4 (33.33\%) agreed to answer 2 and $(16.66 \%)$ normal answer. Based on these data concluded local history in the module has been integrated in the value of the character, it is portrayed in one of the comments that the local historical material is already integrated in the value of community character.

Value characters are integrated in local history, including the value of Maradeka, lempu, getteng, assitinajang, warani. 9 (75\%) stated strongly agree, 3 (25\%) agreed. Based on these data is concluded that the value of the integrated character of local history is representative, it is in line with the comments one respondent that the character value Maradeka, lempu, getteng, sitinaja and warani integrated in the local historical events.

Use of words from Bugis and Makassar in italics. Of the 12 respondents, 9 (75\%) stated strongly agree, 3 (25\%) agreed. Based on the data of the respondents concluded that the use of the word from the Bugis and Makassar discussed in italics excellent for ease in identifying the essence of the material contained in the module. 8) Use of words from Bugis and Makassar followed by a translation. 8 (66.66) respondents strongly agreed and a third (25\%) answered agree, 1 (8.33\%) normal answer. It was concluded from the data that the respondents generally agree with their translated into Indonesian to Makassar Bugis language term used for ease in understanding the content of the material in the module.

Principles of the mind of every sentence is clear and easy to understand. Respondents stated strongly agree 3 (25\%) 5 (41.66\%) agreed, 4 (33.33) normal states. Based on these data is concluded that the main ideas contained in each paragraph has been good. 10) Elaboration or the development of the sentence to sentence meaning is clear and easy to understand. Answered strongly agree 2 (16.66\%), 7 (58.33\%) agree (s), and normal 2 (16.66\%). This illustrates that the elaboration or the development of the sentence to the sentence meaning is clear.

linkage of any material on any interrelated lectures. answered strongly agree 6 (50\%) 5 (41.66\%) answered agree, 1 (8.33\%) normal answer. An assessment of this statement illustrates that any activity related lectures already integrate the character value is evidenced by the percentage who answered strongly agree is 50\%. 12) The transition word to word, sentence to sentence, paragraph to paragraph, subject to subject and lectures to lectures 
clear and easy to understand. Answered strongly agree 1 (8.33\%) 4 (33.33\%) answered disagree and 6 (50\%) normal answer. Based on these data conclude that transitional word to word, sentence to sentence, paragraph to paragraph, subject to subject and activity lectures to lectures clear and easy to understand.

Context / material scope interrelated. 1 (8.33\%) answered strongly agree and 8 (66.66\%) answered agree, 2 (16.66) for normal states. The response to this statement is dominated by very amenable attitude which reached $66.66 \%$ or 8 people. This indicates that the context / ligkup material has been heavily linked between one another. 14) The example given relating to the material. Stated strongly agree 4 (33.33\%), 6 (50\%) agreed, stating normal 1 (8.33\%). Based on the data concluded that the examples given, both illustrations and examples of cases has been strongly associated with the material. 15) The material demonstrated associated with the integration of character education and character values in local history, Answered strongly agree 5 (41.66\%), and agree 4 (33.33\%). Based on these data demonstrated explained that materials related to character education in local history has been very well proven with 5 votes (41.66\%) stated that it could not agree to it. 16) A summary relating to the material presented. Stated strongly agree 7 (58.33\%), agree 5 (41.66\%).

The presentation material and the clear trace. Answering agree 5 (41.66), the normal 7 (58.33\%). In this statement illustrated that basically pretty good student response to local history module based character education. Coverage of the material between character education and local history balanced. Answering agree 9 (75\%), whereas the normal answer 5 (25\%). This statement illustrates that the range of material between character education and local history are complementary and balanced, 9 (75\%) responded to agree. Transition / transfer of the materials on any clear lectures. Answered strongly agree is 6 (50\%), agree 5 (41.66\%) and 8 (8.33\%) normal answer. In this statement revealed that students generally agreed with the transition material each lecture activities clearly evidenced by six (50\%) stated strongly agree with that. Variation of presentation that is used every step clearly. Answered strongly agree 6 (50\%) agreed 3 (25\%),disagree 1 (8.33). Based on these data concluded variations in the presentation that is used every step of the presentation of the material is clear, dibuktian with 50\% stated strongly agree with the statement.

The information and skills delivered relevant and integrated in character education. Answered strongly agree 3 (25\%), 7 (58.33\%) answered agree, 2 (16.66) normal answer. Based on the statement illustrated that the information and skills delivered in local history modulebased education very good character and provide convenience to the students to study the module. Information and keterampialn presented satisfactory. Answered strongly agree 3 (25\%), agree 6 (50\%), and the normal answer 3 (25\%). Based on these data is concluded that the information and skills presented in the modules satisfy, evidenced by three (25\%) responded very satisfactory and 6 (50\%) of them answered agree. Illustration picture presented in accordance with the material by integrating the character values in local history. Answered strongly agree 3 (25\%), 5 (41.66) answered setujudan 2 (16.66\%) normal answer. Against this statement, in general, agree and strongly agree answer amounted to 8, so it concluded that in general students agree or satisfied with this statement. The question in a given task is clear and in line with the material. Answered strongly agree 7 (58.33\%), 4 (33.33\%), answered agree and $2(16.66 \%)$ normal answer. Based on these data conclude that a given task is very clear and in line with the material.

Class of local history-based character education provide new knowledge. Answered strongly agree 10 (83.33\%) 1 (8.33\%) answered agree, 1 (8.33) normal answer 1 $(8.33 \%)$. Based on these data sources to learn the history concluded that locally based character education provide new knowledge for students, evidenced by the 10 (83.33\%) among respondents strongly agree.

Learn the history-based character education is very supportive of alternative references local history lectures. Answered strongly agree 5 (41.66), 7 (58.33\%) agreed to answer. Based on these data conclude that the position of local history-based learning resources supports character education as an alternative to the teaching of local history reference in History Education study program, it is evidenced by the answers strongly agree 5 (41.66) and agreed 7 (58.33). More happy local history-based character education than the local history in the curriculum in history education FIS UNM. answered strongly agree 4 (33.33\%) 8 (66.66\%) agreed to answer. Respondents to it very well, with only select two options, namely strongly agree 4 (33.33) and $8(66,66)$ agrees. Reinforced by comments students who say that it is pleased to learn local history resource-based character education with other references.

The values of character Bugis Makassar presented in local history is very relevant character education based integrated in the activities of intra and extra-campus organizations. Answered strongly agree 2 (16.66\%), 10 (83.33\%) agree. Respondents to this statement indicates that the learning resources can be a supporting character education in campus activities, especially organizing activities. Value of Bugis Makassar characters presented in local history is highly relevant based character education integrated into campus life and social life. Answered strongly agree 4 (33.33\%), 7 (58.33\%) agreed and 1 (8.33) answered disagree. Value of character presented in a very relevant learning resources integrated in campus activities and social life. Local history-based character education implied a lot of character values, especially character Makassar Bugis society. Answered strongly agree is 9 (75\%), answered agree 3 (25\%).The response to this statement is generally explained that the learning resources of local history in the form of local history module based character education is already present value of the character.

Reference character education based local history is very interesting and fun. Answered strongly agree 5 (41.66\%), answered disagree 5 (41.66), the normal answer 2 (16.66\%). Reference alternative in the form of modules, according to the responses of students already draw from a variety of things. 32) Product character education based local history easily understood. Answered strongly agree 3 (25\%), answered disagree 6 (50\%), normal answer 3 (25\%). In general, the response to this, saying local 
history-based products are easy to understand character education.

Interpretation of the data results of the small group trial of local history module based character education can be seen in the following diagram:

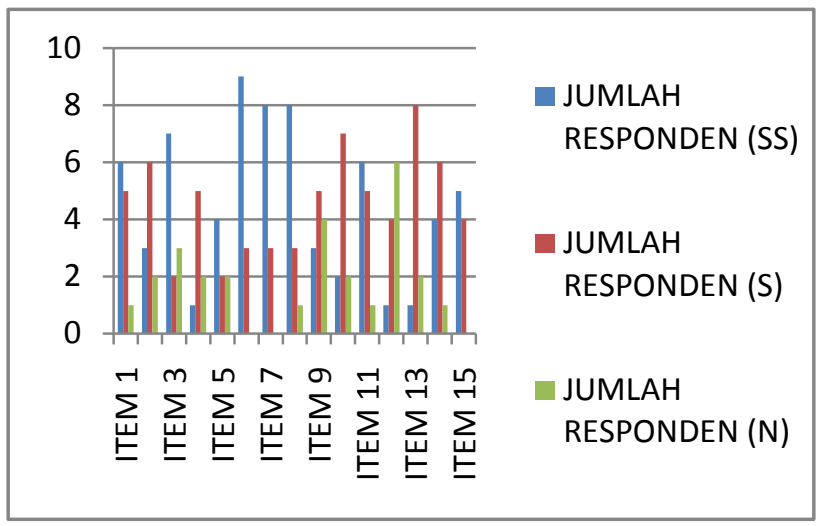

Source: data processed by the researcher, 2017.

\section{Diagram 1.}

Overview of the distribution of respondents to the questionnaire selection trials in small groups sebagaiman described above, it can be concluded that: 1) the student responds positively to their local history resource-based character education as an alternative to local historical references that already exists. 2) design and appearance as well as content-based character education of local history can be said to meet the tastes and interests of students. 3) Local history-based learning resources character education can meet the expectations of the students will learn the local history resources that are integrated on the value of the character. 4) The history of learning materials locally can be said to be effective for use.

\subsubsection{Large group trial (field trial)}

The process of testing to a larger group carried out with the following steps; First, ask for assistance to pegampuh subjects to identify students who will be the respondent in the trial. Total student class of 2014 in History Education study program is 50 people. Determined 35 students into a large group trial. Second, it registers with the format provided the trial participants for research documentation needs. Third, before the student begins learning the exam kompetinsi distributed as a data acquisition instrument before learning competencies. Then provided the modules one by one. Fourth, Researchers explain the purpose and intent test. Students are given exercises as competence competency test as a data acquisition instrument competency after learning implemented, and the seventh, students are given a questionnaire as an instrument acquisition respondents' attitudes towards learning local history-based character education.

The results of a large group trial to test the effectiveness of local content learning materials of local history can be didekripsikan South Sulawesi as follows;

\subsubsection{1. enthusiastic Students}

Post student learning generally assume that the existence of the module local history-based character education is an alternative to the teaching of local history that not only prioritizes capability pedagogic local history but the integration of the character values in each event history can provide new knowledge about the character values implicit in every historical event and exemplary of figures predecessor.

The high enthusiasm of the students in participating in large group trial is one proof that the product of this research received quite positive response from students. With reference to the syllabus and SAP in product research, been one of the subjects, namely the integration of the character values lempu South Sulawesi in local history for implementing the learning before the trial is held. Some of the notes relating to the enthusiastic student research include 1) when the module is shared local history of South Sulawesi-based character education, students respond very well because it has a local historical references that the material contains a local history different from other references. 2) when educators give students the opportunity to ask questions and express their views and experiences on the character values of honesty in the local history of South Sulawesi, students can identify historical events that contain the character value lempu, as well as with the character values implicit in lontara and paseng proposed by to ACCA. Students can also exemplifies contemporary events that are contrary to the values of honesty that has been shown by predecessors. 3 ) the spirit or enthusiasm of students in participating in local history teaching character education based not show saturation hinga end of the lesson for 2x45 minutes. The learning activities concludes with student involvement in filling matter competency test and fill in the questionnaire were distributed.

\subsubsection{Analysis Competency Test Results}

The test results of competence or learning outcomes is the end of the quantitative value of each of the students answered questions on a given problem. While the analysis of the competency test results are quantitative description of the results values of competency test all students for the achievement of basic competence and competence achievement indicator. The process of data acquisition is done by giving a matter before and after the learning activities. The results of the data analysis will illustrate two things namely the achievement of a minimum completeness criteria (KKM) in learning through SPSS analysis.

\subsubsection{End Value Competency Test}

The final value is the competency test student results obtained from the competency test conducted by answering the questions given after following the learning process implemented during the first meetings by using one of learning activities. Pengampuh subjects together researchers chose one of the learning activities with the theme of integration of the character values lempu (honest) in the local history of South Sulawesi. In the test group, the questions used in the form of 40 multiple choice questions. Overview acquisition competency test scores after learning the respondent before implemented. 


\subsubsection{Hypothesis testing}

Table 12. List of participants diidk acquisition value

\begin{tabular}{|c|c|c|c|}
\hline \multirow[t]{2}{*}{ No } & \multirow[t]{2}{*}{ Respondents } & \multicolumn{2}{|c|}{ Scores of competence test } \\
\hline & & Before & After \\
\hline 1 & Aulia Sari & 20 & 35 \\
\hline 2 & Nurul Annami Maghfirah & 21 & 37 \\
\hline 3 & Kusuma Lingrum & 18 & 34 \\
\hline 4 & Pertiwi Nanda Utami & 16 & 36 \\
\hline 5 & Hermawati & 15 & 34 \\
\hline 6 & Mawadda & 15 & 35 \\
\hline 7 & Haeranti provision Sani & 25 & 37 \\
\hline 8 & Nurlinda & 21 & 34 \\
\hline 9 & Nilla Arifin & 19 & 36 \\
\hline 10 & Agus Tri & 16 & 32 \\
\hline 11 & Gustiana & 16 & 35 \\
\hline 12 & Rifka Magfirah & 17 & 37 \\
\hline 13 & Alya Salsa Ramadhani & 25 & 34 \\
\hline 14 & Rahmat Andika & 18 & 36 \\
\hline 15 & Jerwin & 21 & 36 \\
\hline 16 & Desi Safitri & 22 & 35 \\
\hline 17 & Widia Astuti Ansar & 21 & 37 \\
\hline 18 & Fadli Nasrul & 22 & 34 \\
\hline 19 & M.Rijal & 10 & 36 \\
\hline 20 & Abd.Rahman & 16 & 35 \\
\hline 21 & Udayanti U & 20 & 35 \\
\hline 22 & rahmawati & 20 & 37 \\
\hline 23 & Hair Muazzinul & 10 & 32 \\
\hline 24 & Tantri Wulandari & 18 & 36 \\
\hline 25 & Karmilawati & 22 & 34 \\
\hline 26 & Rasky Sri Wahyuni & 11 & 32 \\
\hline 27 & Nana marhani & 16 & 37 \\
\hline 28 & Fajri Muh.Nur R.MK & 17 & 34 \\
\hline 29 & Ully Widasti & 16 & 38 \\
\hline 30 & Anang Agustina & 22 & 35 \\
\hline 31 & Eri Gustiawan & 26 & 36 \\
\hline 32 & Annisa Nurul & 18 & 35 \\
\hline 33 & Nurhanisa & 21 & 39 \\
\hline 34 & Nur Aisyah & 18 & 40 \\
\hline 35 & Warda Pertiwi Mardan & 16 & 34 \\
\hline
\end{tabular}

Source: Data processed by the researcher, 2017.

Overview acquisition value each student as in the above table shows the average value obtained by the student after the following study was 35.4. The rate of return can be concluded that the learning process is going well and the achievement of basic competence was successful because it passes through a minimum completeness criteria (KKM), which is 32 .
The results of data processing with SPSS version 16.0 are as follows:

Table 13. Paired samples statistics

\begin{tabular}{|c|c|c|c|c|c|}
\hline & & Mean & $\mathrm{N}$ & Std.Deviation & Std.Error Mean \\
\hline Pair & After & 35.40 & 35 & 1.802 & .305 \\
1 & Before & 18.43 & 35 & 3.845 & .650 \\
\hline
\end{tabular}

Sumber: Data From Observer, 2017.

Tabel 14. Paired samples correlations

\begin{tabular}{|l|c|c|c|c|}
\hline & & $\mathrm{N}$ & Correlation & Sig. \\
\hline Pair 1 & $\begin{array}{c}\text { After } \\
\text { \& Before }\end{array}$ & 35 & .276 & .109 \\
\hline
\end{tabular}

Sumber: Data From Observer, 2017.

In sequence from the data in the table above can be explained as follows:

\subsubsection{Hypothesis}

Ho: there is no difference in learning outcomes before and after using the local history-based learning module character education.

Ha: there are differences in learning outcomes before and after using the module

Based on out put using SPSS version 16.0 then obtained:

\subsubsection{Comparison of ttable with $t$ count as follows}

The value of tcount is 26.64 while the ttable of 35 respondent data with $95 \%$ confidence level then obtained ttable of 0.45 then it can be seen that thitung $\leq$ ttable thus the decision taken is Ho rejected means there are significant differences in the results of respondents' learning before using after source learning local history based character education.

\subsubsection{Probability Value}

Based on two-sided test value then the value of a (5\%) divided by 2 so that the test criteria become if $\operatorname{sig} \geq 0.05 / 2$ then Ho accepted while if sig $\leq 0.05$ / 2 then Ho rejected.

The SPSS result states that a sig of 0.000 this means that $0.000 \leq 0.025$ then Ho is rejected.

Based on both decision-making methods, it can be concluded that $\mathrm{Ho}$ is rejected which means there is a significant difference between learning result before and after using learning source.

Tabel 15. Paired samples test

\begin{tabular}{|c|c|c|c|c|c|c|c|c|c|}
\hline & & \multicolumn{5}{|c|}{ Paired Differences } & \multirow{3}{*}{$\mathrm{t}$} & \multirow{3}{*}{$\mathrm{df}$} & \multirow{3}{*}{ Sig.(2-tailed) } \\
\hline & & \multirow{2}{*}{ Mean } & \multirow{2}{*}{$\begin{array}{c}\text { Std. } \\
\text { Deviation }\end{array}$} & \multirow{2}{*}{$\begin{array}{l}\text { Std. } \\
\text { Error } \\
\text { Mean }\end{array}$} & \multicolumn{2}{|c|}{ 95\% Confidence Interval of the Difference } & & & \\
\hline & & & & & Lower & Upper & & & \\
\hline Pair 1 & $\begin{array}{l}\text { After } \\
\text { Before }\end{array}$ & 16.971 & 3.769 & .637 & 15.677 & 18.266 & 26.640 & 34 & .000 \\
\hline
\end{tabular}

Sumber: Data from observer, 2017.

\subsection{Discussion}

In the discussion section in the development of learning resources based on local history of character education, will be presented three things; 1) contextualization and learning function of local history of South Sulawesi based on character education from aspect of prodi requirement. 2) synchronization of development module procedure of local history learning of South Sulawesi based on character education, and 3) effectiveness of application of local history of South Sulawesi based on character education. 


\subsubsection{Contextualization of Local History-Based Character Education}

Learning resource based on local resources character education is an alternative reference of local history learning that will be used in Prodi Education History in order to realize the students and alumni who are character. This learning resource can be used to complement existing local history references. This reference is expected to provide new knowledge to students, especially the character values implied in the local history events of South Sulawesi.

The character value implicit in local history events can be a benchmark for students in the daily life, both in campus life and community life, so that with the source of local history-based education character education is a form of inheritance value of the Bugis Makassar community character that can be inherited to the present generation and so that the value is maintained and sustainable in order to realize the generation of character. The effort to maintain national identity must start from the love of value as the main support for the realization of a nation of character. Therefore education-based character education by integrating the value of characters in learning can be done on all subjects, especially local history.

The integration of character values in the local history course introduces students about the value of lempu characters (jujujr), maradeka (democracy), sitaja (kepatutan), getteng (assertive) and warani (bold) characters. The value has been implemented by the kingdom or cendikia figure (to acca) in the past, even some indigenous communities, for example karampuang in Sinjai Regency, kajang in Bulukumba and tolotang in Sidrap Regency still retain the character's value in daily life.

Opportunities to introduce character values by integrating in local history learning are accommodated in the vision of the mission of Makassar State University and the Prodi of History Education. The concept of development should still be based on syllabus and SAP courses, which are technically and substantially determined by the needs of the study program. The integration of character values in local history learning can serve as a first step for other courses to integrate the value of characters in learning. Integrating the value of characters in learning, including in the local history course is an important requirement for the history education program in the effort to realize the students' character.

Substantially local history-based education efforts to recognize and encourage the development of local cultural values to students and institutions with the hope tumbun sense of nationality that diverse tribes, customs and local history and culture can be raised and local history at the national level. Thus, directly or indirectly will grow the love of the State.

Optimizing the function of learning resources based on local history of character education can not be separated from the contribution of educational technology that leads learning activities to be effective, efficient and fun. Educational technology will pay attention to the five domains that determine the success of learning.

The five domains are: (1) Design, design including learning system, instructional message to be delivered, learning strategy will be prepared and analysis of student characteristics; (2). Development, encompassing the development of print, audiovisual, computer-based, multimedia, and integrated technology media; (3) Utilization, encompasses media utilization efforts in learning activities, innovation diffusion, implementation and instrumentalization, policies and regulations that support the effectiveness of learning activities. (4) Management, which includes project management, sources, delivery systems and information oriented to problem solving in learning activities; (5) Assessment, covering aspects of problem analysis, benchmark reference measurements, formative and summative evaluations of all learning planning.

The whole domain is functioning in systems, processes and learning resources related to the local level so that the learning activities can be effective, efficient and fun so as to achieve the standard of competence and basic competencies that are formulated. The development of local history-based learning resources character education is a necessity when the education history of FIS UNM requires. The results of development research to be an answer that is implementationative given the current local history curriculum other than still limited is also monoton so that alternative references can complement other references to support the learning process of local history in the Department of History Education.

The choice of local historical content is based on three foundations of thought based on needs studies. 1) a potential study of the aspects that can be used as a basis for the application of local history based on character education. 2) to analyze the results of feasibility study of the application of local history based on character education in UNM. 3) through interviews conducted on the director of study program, subject faculty and students of History Education of FIS UNM.

\subsubsection{Adjustment of Learning Development Model}

The instructional development models as described in chapter II relating to the choice of development model require harmonization. The harmonization can be either a merge or modification of two or more models. In the design of the learning system, the model describes the steps or procedures that need to be taken to create an effective, efficient, and interesting learning activity. The model can also be interpreted as a concrete form that can be observed and seen by naked eye. In a model is usually contained a number of components that characterize a reality and logically connected. The model is also a presentation of a process in the form of free or narrative, by showing the main elements and structure.

Opportunities to modify from various models because the development of learning resources is an innovation in education. So a model in the development of learning is a systematic process in the design, construction, utilization of management, and evaluation of learning systems. The above explanation can be used to describe the model in the intention of this research that is the conception of a model that represents a system of knowledge designed for learning activities based on local history character education.

The result of the modeling of learning model yields an alternative model and an existing model. Models of learning modify between MPI and local historical development procedures based on character education. Specific data model development of learning resources 
based on local history of character whose basic needs are determined by the Prodi Education History certainly has its own characteristics and can not be generalized. Therefore, the development of local-based learning resource-based character education in this study has set a modification model.

\subsubsection{The Effectiveness of Application of Learning Resource Development of Local History Based on Character Education}

Measuring the level of effectiveness of the application of learning resources based on local history character education can be seen from 3 aspects; first, the acceptance of students to the position of local history-based sources of character education becomes an alternative source of learning that integrates the value of characters in learning that there has been no source associated with the integration of character values. This can be seen from the interviews with the students who showed high expectation on the application of local history based on character education in accordance with the needs of the students and the needs of the study program.

Second, the support of local history lecturer. Based on the results of the interview illustrates that the main problem in local history learning so far is the absence of reference based on syllabus and SAP local history courses. In addition, local history learning has been considered very monotonous because it only prioritizes the knowledge of history to the local-an without revealing the value of the characters implied in historical events.

Third, the study program and the university and all the elements of an alternative source of learning of local history whose content is more in line with the historical and cultural background of the Bugis Makassar community. This can be seen from the record of interviews with the leaders, faculty and students. In general, they expect a review of the application of local history based on character education that is considered inconsistent with the needs of students and alumni. The effort of preserving and developing local historical and cultural values on the younger generation is only through the most strategic learning activities.

\section{Conclusion}

The research process of developing local South-Southbased learning resource based on character education is done in accordance with the research stage. The result of the research is the product of learning guidance and local history module of South Sulawesi based on character education. The whole process of research that has been done then can be drawn conclusion as follows:

1. The study of local history in FIS History Studies Program of UNM at this time, especially in the use of references only rely on references that contain about the local history of South Sulawesi, without integrating the character value so that the resulting output is the students only have pedagogic ability to local history events in South Sulawesi.

2. The inability of students in identifying, integrating and applying the values of the character of the people of South Sulawesi is a very basic problem so an alternative reference is required in the teaching of local history. This research provides one of the solutions in introducing character values with the development of local history-based learning sources of character education in the form of lecturer's modules and guidelines.

3. The process of developing learning resources of the local history of South Sulawesi-based character education based on the Learner Instructional Model (MPI) that can be justified scientifically. Usefulness in terms of research results can be said to have been in accordance with the needs of the study program of history education, so that the products of local history-based learning resources generated character education can be a prototype for developing learning materials on other subjects.

4. Learning resources development research procedure using Instructional Development Model. The stages of development started from; a) identification of needs Prodi and define competency standards, b) analysis of instructional, c) identification of the characteristics of students, d) determine the basic competence, e) develop syllabi and SAP, f) designed the system judging, g) develop learning modules, h) designing and implement formative evaluation. The results of the procedure of the development of local history-based learning resources character education has been adapted into learning guidelines that describe the concept and practical learning about local history-based character education.

\section{References}

[1] Jennifer Frost, "Using” Master Narratives "to Teach History: The Case of the Civil Rights Movement”, The History Teacher Journal Archives 2015, Vol 45 No. 3, h. 444.

[2] Directorate General of Primary and Secondary Education Management Ministry of National Education, Character Education Formation Model in School (Jakarta: Kemendiknas, 2010), pp. 64-65.

[3] Ole Boe, Henning Bang, Frederick A. Nielsen, "Selecting the Most Relevant Character Strengths for Norwegian Army Officers: An Educational Tool”, Journal Procedia-Social and Behavioral Sciences, Vol. 197, Elsevier 2015, p. 804.

[4] Murty Marga Pane \& Rina Patiana, "The Significance of Environmental Contents in Character Education for the Quality of Life", Journal Procedia-Social and Behavioral Sciences (Procedia), Vol. 222, Elsevier 2016, p. 247.

[5] Edward Vickers, "The Politics of History Education in Hong Kong: The Case of Local histoy”, International Journal of Educational Research, Vol 37, Pergamon, 2012, p. 596.

[6] Diana Trisnawati, "History Learning Module Development bebasis Improving Character Education in Nationalism in the School of Education Special Services Foundation Girlan Nusantara”, Journal of Character Education, Vol 10 No 2, Yogyakarta 2015, pp. 47-48.

[7] Simion Minodora Otilia, "Needs Analysis in English for Specific Purposes”, Journal Annals of the Constantin Brancusi, Vol. 2, University of Targu Jiu in 2015, h. 54.

[8] Nurul Haque, “A Brief Study on Needs Analysis”, International Journal of Multi Disciplinary Research, Vol 1, JCPH Queensland University of Technology Brisbane Australia, 2014, p. 2.

[9] Ladda, Silanoi, "The Development of Teaching Pattern for Promoting the Building up of Character Education Based on Sufficiency Economy Philosophy in Thailand”, Journal ProcediaSocial and Behavioral Sciences, Vol. 69, Elsevier, 2012, h.1813. 
[10] Keith Trigwell, "Evidence of the Impact of Scholarship of Teaching and Learning Purposes”, The ISSOTL Journal, Vol. 1, the International Society for the Scholarship of Teaching and Learning is Collaborating with JSTOR, 2013, pp. 97-98.

[11] Gulcin Mutlu, An Analytic Look at a Language Course Design Model, Journal of Education and Teaching, Vol. 4, IOJET 2017, p. 346.

[12] Florence Martin, "Instructional Design and the Importance of Instructional Alignment", Community College Journal of Research and Practice, Vol. 35, Rotledge 2011, p. 956.

[13] J. Michael Spector and Susanne Lajoie (Editor), "Designing for Learning in an Open Wold”, Springer, Vol 4, New York Heidelberg Dordrecht London, 2013, p. 7-8.

[14] Muhammad Yaumi, Principles of Learning Design (Jakarta: Gold, 2013), h.247.

[15] Muhammad Yaumi, Principles of Learning Design (Jakarta: Gold, 2013), P. 251.
[16] The Higher Education Academy, Independent Learning; The Information on Reviews These Pages has Been Developed as part of the Teaching International Students Project (USA, 2014), p. 3.

[17] Charles M. Reigeluth, "Instructional Theory and Technology for the New Paradigm of Education", Revista de Educacion a Distancia, Vol XI No 32, Espana 2012, pp. 2-3.

[18] Richard Caladine, Enhancing eLearning with Rich Media Content and Interactions (Hershey: Information Science Publishing, 2008), pp. 56-57.

[19] Jolly T. Holden, Philip JL Westfal, An Instructional Media Selection Guide for Distance Learning (New York: USDLA 2009), h.13.

[20] Syafruddin Nurdin \& Adriantoni, Curriculum and Learning (Jakarta: Rajawali Press, 2016), pp. 272-273.

[21] TIM Lloyd's, Solvency II Model Validation Guidance (London: Lloyd's, 2014), p. 34.

[22] Nuhung Ruis, Muhyidi and Tri Waluyo, Intructional Media (Jakarta: Ministry of National Education, 2009), p. 10. 